\title{
VENICE ARSENALE: TOURIST MAGNET AND THE RETURN OF INNOVATION
}

\author{
C. CLARK \\ Wessex Institute of Technology, UK.
}

\begin{abstract}
The Arsenale in Venice, both a naval dockyard and a commercial shipyard, is the prototype for industrial production in the western world. The magnificence of its architecture and industrial structures reflects the creativity of its management and the commercial power of Venice in the Mediterranean, but they also present a challenge to present-day conservation and the search for contemporary reuse. Heritage tourism is often seen as the most appropriate new activity for historic defence sites, but the overwhelming dominance of visitors generated by the Biennales of Art and Architecture, which are taking over an increasing area of the Arsenale, is contributing to the increasing depopulation of the city. Technological innovation and research in the northern part is a welcome diversion from this process.

Keywords: architecture, Arsenale, depopulation, heritage tourism, innovation.
\end{abstract}

\section{INTRODUCTION}

The Arsenale is probably the oldest of the historic naval waterfronts in Europe affected by contraction and restructuring of national navies, some of which are being impressively revitalized. Many of the surviving structures are industrial buildings of exceptional rarity. Given its symbolic importance as the vital generator of the Republic's prosperity as well as one of Europe's earliest industrial complexes to employ mass production, the challenge of bringing new life to its fragile buildings and infrastructure is considerable; however, ever-increasing tourist numbers, including those attending the Biennale, which occupies part of the southern part of the Arsenale, are severely damaging the city's social fabric.

Deep-seated problems, such as the relative inflexibility of the resources released for reuse by defence-related contraction, not least if they are fragile historic buildings, were recognized by the Commission of the European Union, which offered assistance to former defence sites, via Konver, Renaval, Network Demilitarised, PACTE and PHARE. These linked local governments affected by defence cuts to exchange experience and research appropriate ways to attract investment, new enterprises and to fund renewed infrastructure in order to replace monolithic state investment with a more diverse economy. The European Union (EU) directly finances the conversion of historic naval buildings to new uses and key infrastructure such as the conversion of the Arsenale mast tower to a conference centre and the vital lagoon gates constructed in its drydocks.

Specific studies of defence site transitions to civilian uses include the special edition of Volume 42 of Ocean and Coastal Zone Management (1999) on the issues, potential, opportunity and challenges of heritage resources and naval port regeneration. Clark and Pinder examined issues arising from the future of the Arsenale [1]. International conferences about defence sites' history and future offer opportunities for exchanges of experience across different countries. In 2012 a conservation pressure and research group, Europa Nostra: 'The Voice of Cultural Heritage in Europe' in The Hague, took an interest in the problem. Its

This paper is part of the Proceedings of the 3rd International Conference on Defence Sites: Heritage and Future (Defence Heritage 2016)

www.witconferences.com 
Scientific Committee published conference proceedings held in Istanbul on the Reuse of Ancient Fortified Settlements from the Middle Ages to Early Modern Time, and in 2014 it published the papers from a conference on Heritage Conservation and Enhancement in Former Conflict Zones, held in Nicosia Cyprus [2, 3].

\section{THE ARSENALE'S HISTORY IN BUILDINGS - 'A CITY WITHIN A CITY'}

Planned in its present form in the 13th century the Arsenale is a prototype of dockyards and early industrial production in the western world [4]. The Venetian maritime Republic dominated the Mediterranean in the 15th and 16th centuries, in large part due to its strategic advantage in sea power - in both the size of its military and merchant fleets and the quality of the ships in them [5]. Venetian shipbuilders produced some of the best designed and built fighting ships available. The role of the Arsenale was crucial. From 1302 a monopoly forbade shipbuilding for the state anywhere else [6]. Inside its walls as harbour and factory for the Republic's ships and artillery it was the motor of the city's wealth, a centre of vital craft skills employing almost 16,000 people at its peak. Dante celebrated it in the Divine Comedy's Inferno, after his visit in 1312. At its apogee in the 15th century it was regarded as the eighth wonder of the world: medieval Europe's largest industrial complex. Luca Zan's close reading of the rich original documents in Venetian [7] sets out the Arsenale's sophisticated accounting and management discourses in the Renaissance period, including the invention of the idea of work in progress and the Venetian method of double entry bookkeeping at the turn of the 16th century. Together these enabled new time-sensitive, dynamic notions of measurement of the work to be done against the manpower required to do it.

Between the late 14th and 15th centuries Venetian trade routes extended to England, Flanders and Portugal in the west, to Constantinople, Tana and Trebizond around the Black Sea in the east, and south to Alexandria and Tripoli in North Africa. Shortly before the battle of Lepanto in 1571 against the Ottoman Empire the Arsenale was launching seven shallowdraught galleys suitable for the shallow Adriatic a month. The authorities of the Venetian Republic viewed the Arsenale as a city within a city, the repository of vital craft skills and a symbol of state power [8]. In the 16th century a design policy was adopted to transform the Arsenale into an architectural showpiece to match the magnificence of the city [1]. The English Surveyor of the Navy Edmund Dummer (1651-1713), who designed and supervised the construction of the Royal Naval dockyard at Plymouth and the extension of Portsmouth dockyard, made careful notes of the construction of the Arsenale's covered wet docks, publishing his findings in A Voyage to the Mediterranean Seas in 1685.

The public face of the Arsenale is the extravagantly ornamental Porta Magna gate to the Arsenale with its triumphal arch of 1457-1460, modelled on the Roman gateway in Pula. Probably designed by Gambello, it is one of the earliest Renaissance works in Venice. It incorporates classical columns embellished with capitals and other fragments from Byzantium, guarded by four salvaged lions added in 1687 , one with runic inscriptions on its flanks recording the Vikings' capture of Athens, once another great maritime empire, in the 11th century [9]. The eastern lion, with its replacement dog-like head was looted by the Venetians from Delos, capital of the Delian League [8]. The adjoining water gate and canal is still the navy's main access point. There is a small naval barracks inside: the navy still uses the basin and the western area. On the south side of the Darsena Grande (basin) are the Tezoni Gotici of 1457 , two very wide span wet docks, resting on stone and brick arcades. They are covered with massive trussed timber roofs morticed in larchwood bound with iron straps.

Between 1568 and 1573 the magnificent Gaggiandre double span wet docks are attributed to Jacopo Sansovino, the Florentine architect whose masterpiece is the library of San Marco 
(1537-1544) opposite the Doges' palace. Three parallel rows of Istrian stone Doric columns support brick arcades on which rests a massive timber-framed shallow-pitched roof, which dates from the 13th century [1], under which several vessels could be repaired in secret. Galleys' shallow draft meant that they could be repaired while still afloat. The Gaggiandre was a part of restructuring of dockyard production by Vittorio Fausto in order to achieve both horizontal integration (roofed pavilions, standardized equipment and assembly lines) and vertical (planned forestry, timber inventories and pre-assembly of naval equipment). Claudio Menichelli of the Soprintendenza Belle Arti e Paesaggio per Venezia e Laguna, the local heritage agency, supervised all the restoration work on the buildings of the Arsenale over 20 years.

The Corderia della Tana ropewalk was magnificently rebuilt between 1577 and 1583 by da Ponte, the architect of the Rialto Bridge and the Bridge of Sighs. Because of its function it is easily the longest building in the Arsenale: a thousand Venetian feet or 3,015 m. Attaching it to the southern outer defence wall along the Rio della Tana made cost savings. The interior is dominated by a double row of Doric columns, which were originally designed to support masonry arches, thus creating the world's first fireproof building. Its massive entrance door which breaches the southern wall was added in 1779, the only Arsenale building with direct access to the city, a key factor which enabled its later use as an exhibition space.

In about 1750 the Squadratori, a shipwrights' school with classrooms above and workshops below was added on the west side of the basin. Further expansion in 1810 followed the capture of Venice in 1797 by Napoleon's forces and the city's transfer to the Austrian empire under the Treaty of Campoforno. The impressive range of the Capannoni (storehouses) along the north side of the basin were rebuilt under Austrian occupation following the Napoleonic conquest of Venice with white stone columns punctuating their brick facades and shallow inset arches framing triple openings [1].

The cavernous spaces of the tall Masting Sheer tower in Venice Arsenale once housed a huge wheel in the giant first floor to raise ships' masts to install them in vessels moored underneath. It was designed by French engineer Lessan under Napoleonic rule and was completed between 1809 and 1810 at the time of Austrian domination. Known as the Dutch tower, its design was based on northern European models, but its wooden jib and wheel quickly became obsolete, especially after the huge hydraulic heavy duty Armstrong crane was installed [10]. A new mechanism invented by William Armstrong: the hydraulic accumulator, forced large quantities of water through pipes at a constant pressure, creating more power to lift heavier weights up to 160 tons. It was built in Newcastle upon Tyne in northern England and installed in the central basin for the Italian navy. It is now the only one surviving in the Mediterranean [11]. Following the unification of Italy in 1871 the Arsenale became a state property and naval base. In 1866 reclamation to the northeast provided space for more buildings and the construction of two drydocks in 1870-1871 and 1910-1911.

\section{DECLINE AND REBIRTH}

Once the vital engine of the Republic's prosperity, the Arsenale was in decline for most of the 19th and 20th centuries. Its 16 hectares were for most of that time the 'dead heart of the city'. Over the years it was the focus of many proposals, some of which thankfully did not take place. In the early 1990s Admiral Gottardi, joint chairman of the Committee for the Preservation of the Arsenale, proposed a 350 boat marina in the main basin. He hoped that each boat would create three jobs - for work on hull, engines and sails - a considerable overestimate, when there are other more accessible and highly serviced havens for yachtsmen in the Adriatic [12]. Instead, from 1980s the magnificent Corderia della Tana and several other restored buildings have been in regular use to house the Biennales of Art and Architecture and for other exhibitions [13], a 
harbinger of renewal for much of the site, but with the risk of intensifying visitor pressure on local people. The Italian navy retains one-third of the Arsenale, which in total is still $10 \%$ of the city's land area; this study examines what has happened to the remainder.

In the early 1990s Città d'acqua, a consortium of commercial and academic interests whose focus is water as a resource and potential means of improving the quality of urban life, promoted the idea of the Arsenale as a water gate to the city as a counterbalance to the already overloaded land gate. An attractive idea - one of the world's great travelling experiences is arriving in Venice by water - though perhaps the needs of local people, not least for non-tourist employment, should come first. In the late 1980s a vast international exhibition was proposed for the Arsenale by Gianni de Michelis, Italy's Foreign Minister, but opponents said it would complete the Disneyfication of the city. Opposition was international as well as local: the Pink Floyd concert held in Piazza San Marco was an awful warning of what an even larger event might do to Venice's fragile historic infrastructure: it required a clean-up by the military. The Expo 2000 proposal was defeated, but the problems of Venice remain [9]. Delay in finding an acceptable solution for future uses of the Arsenale was seen as beneficial for many years, preventing a carve-up of the site between different political groups. But the increasing state of decay in the unrestored sections gave urgency to the task. Regeneration of its ancient buildings continues. From the 1990s new activities, cultural tourism and skilled job creation in maritime research and engineering have arisen, the buildings restored by a combination of the state, the environmental agency and the commune.

In the naval area the Tezoni Gotici were restored with help from the University of Architecture. Corvettes are moored in the main basin, and the submarine Dandolo is hauled up onto a white stone ramp. Ten years ago the navy began to convert the monumental mould loft, the Squadratori built by Giovanni Scalfarotto of 1750 to train shipwrights above a workshop [14]. But after repairing the roof, funds to finish the conversion still have to be found. The Istituto di Studi Militari Marittimi (Naval Staff College) is in the Palazzo San Martino inside the Porta di Terra, which also houses the navy's history library. In 1999-2004 after the Istituto moved from Livorno to the Arsenale, Admiral Pagnottella set up the Ufficio Progetto Arsenale (Arsenal project office) with a plan to move the Museo Storico Navale di Venezia from the nearby Riva S. Biasio to the capanoni, redisplaying and interpreting the artefacts and adding the many artworks scattered around Italy, with university research laboratories. The restored Squadratori was to house the Istituto di Studi Militari Marittimi and to host international maritime conferences. But this proposal, which is still on the table, needed backing from the state, which was not forthcoming [14]. One project that is going ahead is the reconstruction of the gilded state barge of the Doges, the Bucintoro. Every Ascension Day the Doge threw a ring from the barge into the Adriatic to symbolize the city's 'Marriage to the Sea'. The last and most magnificent Bucintoro built in 1729 and depicted in famous paintings by Canaletto and Francesco Guardi was destroyed by Napoleon in 1798 to symbolize his victory in conquering Venice. The $€ 20$ million rebuilding of the replica was started in 2008 in a canal side covered slip in the Arsenale. In 2013 France donated 600 oak trees for it from the forests of Aquitane [15]. Richard Haslam of the Venice in Peril Fund would like to see this followed by recreation of a galleass, one of the formidable oar powered warships which were built there [16]. None of this area is open to the public, though it used to be visible from the vaporetto until that was rerouted around the outside walls to avoid damage to the canal banks; it is visible but not accessible from the other parts of the Arsenale.

The search for a successor body to take on, restore and introduce new activities to the rest of the Arsenale did not include the creation by the state of independent historic dockyard trusts, like those which were given responsibility for the mainly 17 th- to 20-century historic cores of Chatham and Portsmouth naval bases in the 1980s. Differences between the British and 
Italian legal systems may have prevented the exact replication of this strategy in the Arsenale [1]. The potential of local authorities to take on and gain from acting as catalysts to regeneration was demonstrated in Karlskrona in southern Sweden, where the local authority acted as the agent of change when the navy no longer needed the victualling island of Stumholmen. This had been developed in 1680 to supply the nearby dockyard. The municipality purchased the site at military use value (rather than market value - a key factor in eventual land use outcomes), and carried out an extensive public consultation exercise and exhibition which attracted 80,000 visitors. Architects were appointed through open competition and a land use plan was agreed. As in Venice, where state investment took the form of repair of key historic buildings, central government also contributed to regenerating the Karlskrona economy: many civil servants were transferred from the housing office in Stockholm and a new Maritime Museum was constructed on the redeveloped island. Following the grant of planning permission for mixed uses, the local authorities gained from the resulting increase in land values. They selected the developers and sold the site on to new owners [9].

In Venice, by contrast, since 2013 the municipality has played an increasing role in bringing the site back to life, but not via external bodies or developers, but ultimately as owner. On 6 February 2013 the government in the form of the Navy (Demanio Militare) and Venice Municipality reached agreement over the ownership of the Arsenale. The city now controls $70 \%$ of the area of the base, while the navy retains the oldest part and the basin [14]. The new activities include art exhibitions, conferences, maritime and marine research and engineering manufacture. In 2015 the Italian state - in the form of the Soprintendenza - the local heritage agency - the navy, the Biennales of Art and Architecture and the Comune di Venezia (city council) were gradually restoring the Arsenale's fragile buildings and infrastructure. Its historic buildings and the Armstrong crane present specialized conservation challenges and considerable future investment if sustainable reuse of them is to be achieved.

\section{THE RETURN OF INNOVATION AND INDUSTRY TO THE ARSENALE}

Perhaps in acknowledgement that skilled job creation is as important as tourism to the city's future, in the northern section of the Arsenale across the canal to the Porta d'Acqua, industry has become the new use in the last area to be restored and reused. This process began in the 1990s when an offshoot of the university and local marine industry: Thetis, which is focused on underwater and coastal research and the impact of climate change, restored and converted a 'Capannone tesa' (storehouse) and a 1910 foundry on the north side of the basin for its laboratory. Strict conservation rules prevented any impingement to the walls, so the lab is free standing inside the space [9]. Thetis is now the centre of an international network for development of coastal best practices and underwater research. Restored storehouses and the impressive mast tower are occupied by specialized firms and charitable foundations such as Corila (Consortium for Co-ordination of Research Activities Concerning the Venice Lagoon System) and ACTV (the transport authority).

From 2011 the control centre for MOSE (MOdulo Sperimentale Elettromeccanico, Experimental Electromechanical Module) to protect the city of Venice and the Venetian Lagoon from flooding has been based here, stimulating restoration of decayed and abandoned historical and architecturally important buildings for this huge engineering project financed by the Italian government $\mathbf{v}$. High tech lifting equipment is visible as the vaporetto comes round the Arsenale's wall. The first lagoon gate designed and built on site by the Consortio di Venezia Nuova was put in place in late October 2014 and test run in February 2015. It will take another year and a half to complete the project; a financial scandal has enveloped it. The three water filled gates lie on the sea floor; when a tidal surge in forecast, they are filled with compressed area, and when fully raised they form a barrier to protect the city from flooding [17]. 
Public access to the central basin from the new vaporetto stop is through a central storehouse: 'Tesa 105' elegantly converted to a café and exhibition area by Arsenale di Venezia Spa (a State and city of Venice company). The three dry docks of 1875, 1910 and 1917 had been used for ship repair. Arsenale Spa, a company set up by the state and the municipality of Venice with a mandate to restore and enhance the Arsenale complex went into liquidation in 2013. This stimulated the formal transfer of this part of the site - for free - to the Comune of Venice via a State Law of 2 February 2013, which confirmed the tenure of the institutions already on the site, such as the Biennale, the former Magistrato all Acque, ISMAR: the national research institute and Thetis.

In 2011 the Masting Tower was elegantly restored and converted as a conference venue at a cost of €4.2 million by architects Magnani and Pelzel of Studio Map following an architectural competition. The ground floor houses the auditorium, with a cleverly angled acoustic baffle with projection facilities. The enormous vaulted first floor, which housed the giant wheel, is now reached by a new lift and stairs. The space was deliberately left empty. A lift and modern stair alongside the original vertiginous staircase and ramps lead to the rooftop terrace. The restoration and conversion was financed by the EU Regional Development Fund Second Chance - From Industrial Use to Creative Impulse. The new facility was opened in 2011. As you know, the Wessex Institute of Technology arranges conferences on Defence Sites: Heritage and Futures. The first was in Portsmouth UK in 2012. The second took place in the appropriate setting of the Masting Tower in Venice Arsenale in 2014 [18-20], and the third is here in Alicante in 2016. The objectives of the conferences are to increase knowledge of the scale, design and functions of defence sites, and to deepen the understanding of the implications of different disposal processes for state-owned land; the issues raised by their redundancy and the search for sustainable new land uses, to bring compensating benefits to formerly defence dependent areas. The northern area of the Arsenale was open to the public on Heritage Open Day 20 September 2014.

\section{TOURISM AND ITS DOWNSIDE FOR VENICE}

The influential 19th century art and social critic and artist John Ruskin was the first to anticipate what tourism might do to Venice. He first visited the city in 1835 when it was in a state of decay, but he saw that restoration combined with modernization did yet more damage. He campaigned successfully to prevent a brutal restoration of St. Marco's. He wrote The Stones of Venice (1851-1853) there, focussing on the city's Gothic architecture, which represented an ideal society, devoted to noble art and faithful religion. His guidebook was intended for 'the few travellers who still care for her monuments', but he was horrified by the rise in tourism facilitated by tours by Thomas Cook - and its impact on the city [21]. As this chapter demonstrates, in the case of the Arsenale and for the city as a whole, his premonition was all too accurate.

'Heritage tourism' is often seen as the most appropriate use for historic defence sites - after they lose their prime warlike purpose [22]. The United States National Trust for Historic Preservation defines heritage tourism as 'traveling to experience the places, artifacts and activities that authentically represent the stories and people of the past,' and 'heritage tourism can include cultural, historic and natural resources' [23]. As Timothy and Boyd [24] point out, heritage is not simply the past, but the modern-day use of elements of the past. The legacy of past structures are not conserved for their intrinsic merit but are presented as part of a definable product to a recognized market [25]. Tunbridge and Ashworth [26] argue that heritage that has passed through an economic filter takes on an economic function, and it is around this that a heritage industry has emerged. 
The city's economy is now so dominated by tourism that its social effects including depopulation are reducing the city's economic and social viability. Venice's population has declined rapidly since the 1950s. After the disastrous flood of 1966 it almost halved - from 121,000 to 62,000 . The ground floors of some 16,000 houses were abandoned. The growth of mass tourism, combined with rising water levels, has made living in Venice increasingly challenging. Since then the register of inhabitants shrunk by 800 a year; in $2005,1,918$ more people moved out or died in Venice than moved in or were born there. In $200625 \%$ of the population was over the age of 64 . When you witness the huge effort required to haul someone wheelchair-bound over the high canal bridges you realize just how hard daily life can be for older or physically handicapped residents. The council estimated that the rate of decline will increase to between 2,000 and 2,500 a year. A digital counter in a shop window near the Rialto Bridge installed by Venssia.com, a group dedicated to protecting the Venetian way of life, shows the numbers ebbing week by week. On 8 November 2012, it displayed a new low: 58,483 [27], outnumbered by the 60,000 people who visit the city every day.

Those that remain find their daily lives impeded by 'tourist hordes' crowded into a comparatively small area. Even in the 1980s the tourism tide numbered six million, more than three quarters of them day trippers. In 2008 tourists numbered 21 million. L'Annuario del Turismo 2014 - Dati e trend gives the number of arrivals as 4,280,632 and the number of bed nights as 9,983,416 for 2014 [28]. When the numbers threaten to become overwhelming, the land access by the causeway across the lagoon is closed, cutting Venice off from the world except by water. From the 1980s this happened as early as April. In 1987 there were 156 days when the number of tourists exceeded 25,000 , with peaks of 60,000-100,000 on at least six days. To the detriment of the remaining Venetians, tourist-related activities are replacing other commercial concerns and residential accommodation: groceries become souvenir shops, chemists become jewellery boutiques, local bars are converted into pizzeria or other fast food restaurants. Modern services moved to the mainland, and according to the Venice council housing director, Maria Rumiz, depopulation of the city is getting to the point of no return. A city that once ruled an empire now has a smaller population than Herne Bay - a seaside resort in southern England - and if it continues to lose full-time inhabitants at the same rate, the city council calculates that it will be 'empty' by about 2046 . That does not mean that the city will be without inhabitants, because foreigners and Italians are continuing to buy second homes in Venice, but it does mean the native Venetian is an endangered species. House prices have soared beyond the reach of all but the richest. Venice may then become a museum city - a place to which as La Repubblica remarked, it would be 'normal to charge entry ... In 2008 around 20 million tourists visited Venice each year (the equivalent of almost 55,000 a day), bringing in cash but also stretching its infrastructure and resources to the limit' [29]. Tourist pressure is exacerbated by a $439 \%$ increase in cruise dockings in the previous 15 years. The Biennales of Art and Architecture which occupy the southern part of the Arsenale contribute to this pressure, attracting larger and larger tides of tourists as explored below.

The Biennale of Art began in 1895 in the Giardini with its permanent national pavilions. After a six-year break during World War II, the exhibition was resumed in 1948, showing avant-garde art from across the world. The Biennales have gradually colonized more and more of the Arsenale buildings [30, 31]. As Ray Riley and I discovered on a visit to Venice some years ago, the end of the magnificent Corderie was converted into a lecture theatre used by outside organizations for conferences. In autumn 2006 the 10th international Biennale of architecture was on the theme Città Architettura e società - in the very year that half the world's population became urban. According to the United Nations, this number is set to 
rise to $75 \%$ by 2050 . 'Understanding the impacts of this growth on people and on the environment has become a necessity, as the links between architecture and society become both more complex and more fragile. How we choose to shape our cities, buildings and public spaces - as architects, urbanists and city makers - will determine how we respond to the challenges of climate change as well as addressing human rights, justice and dignity for the billions of people who move to cities in search of work and opportunity' (www.labiennale. org, 2006). Using an ancient brownfield site to put across this message was particularly apposite.

In 2004 the Venice in Peril Fund paid over $€ 100,000$ for emergency safety work and initial investigations towards repair of the towering hydraulic Armstrong, Mitchell \& Co. In $2013 € 15,000$ was spent reinforcing the straps that hold the ballast container together and to update the report on its condition. Phase I of the full project is costed at $€ 390,000$ and a further approximately $€ 1.6$ million will be needed to complete the project [32]. In the areas conceded by the Demanio Militare $50,000 \mathrm{~m}^{2}$ (25,000 of which is indoor space) in the southeast area have become the second permanent site for Biennale activities. The Corderie, Artiglierie, Gaggiandre, Tese Cinquecentesche, Tese delle Vergini and the lovely garden are used as exhibition spaces. Live performances take place in the Teatro alle Tese and the Teatro Piccolo Arsenale. In 2009 the exhibition space was extended from 800 to $1800 \mathrm{~m}^{2}$ by restoring several of the southern covered slips with new concrete floors. In 2011 a new entrance was opened from the Ponte dei Pensieri, linking the two Biennale sites: the Giardino delle Vergini and the Arsenale in the Castello district together [33]. In 2014 the duration of the biennale was extended - the exhibition opened in June and closed in late November. 228,000 visitors came in addition to the 12,214 who came to the previews. Forty-five per cent were young people and students: a huge increase from the 178,000 visitors who came to the threemonth opening in 2012 [34].

But for the majority of the site and for Venice as a whole, 'Tourism is a double-edged sword,' said Peter Debrine, head of the World Heritage and Sustainable Tourism Programme at UNESCO, in an interview with Deutsche Welle. 'You can't have those kind of numbers come into a site and not have a negative impact.' 'Venice's economy is almost entirely dependent on tourism,' he said. 'They need the tourists. But, it is also essentially a museum that needs to be preserved. A balance has to be struck.' [35]

The cruise ships cause tidal waves that erode the foundations of buildings, contribute to pollution and have an impact on the cityscape as they dwarf the city's monuments. Many Venetians will readily acknowledge the economic boon from tourists. According to the Cruise Venice Committee, cruise ship passengers spend more than $€ 150$ million (\$193 million) annually in the city. More than 650 ships visit the city's port each year, and each ship provides additional money from docking fees and purchasing supplies such as food and water from local contractors. The cruise sector also employs an estimated 3,000 Venetians. In 2009, residents held a mock funeral to symbolize the city's decline, followed by another event a year later, in which they handed out maps and free 'entrance tickets' to 'Veniceland.' But the colourful protests, which drew international attention and have led to regular dialogue with local government leaders, have not slowed the ever-increasing stream of tourists, including those arriving on cruise ships.

In September 2014 the Italian government agreed to limit the flow of large cruise liners with a gross register tonnage exceeding 96,000 GRT through the central St. Mark's lagoon on environmental grounds: a tough balance to strike between ecology and tourism. Most of the more than 600 cruise ships to dock in Venice each year would not be affected [35]. 


\section{CONCLUSION}

The welcome diversification into skilled industrial construction and marine and maritime research in the northern part of the Arsenale begun by Thetis and accelerated under the Commune's ownership is both historically appropriate and a positive contribution to employment for Venetians, but it does not counterbalance the heavy social price they pay for the continuing overwhelming dominance of tourism - in turns not only of jobs but also of environmental damage by enormous cruise ships in the Giudecca Canal. Local politicians hesitate to exclude them from the central waterway of Venice for fear of losing tourist revenue. The city as a whole is a World Heritage Site but heritage tourism may continue to place unacceptable pressures on fragile environments such as Venice: visitors' experience needs to be carefully managed in order not to damage historic structures or ecology - and diversification into other employment should be developed to counterbalance the dominance of tourism.

\section{REFERENCES}

[1] Clark, C. \& Pinder, D., Naval heritage and the revitisation challenge: Lessons from the Venetian Arsenale. Ocean and Coastal Management, Volume 42, Numbers 1011, ISSN 0694-5691, 1999. Special Issue Heritage Resources and Naval Port Regeneration, eds. D. Pinder \& H. Smith, pp. 933-956, 1999.

[2] Perbellini, G (ed.), The reuse of ancient fortified settlements from middle ages to early modern time. Europa Nostra Scientific Council, Scientific Bulletin 65 European Commission, A.G. Leventis Foundation: The Hague, 2012.

[3] Perbellini, G. (ed.) Heritage conservation and enhancement in former conflict zones underground defences and fortifications Europa Nostra Scientific Council Scientific Bulletin 66-67, European Commission, A.G. Leventis Foundation: The Hague, 2014.

[4] MacDougall, P., Email to Celia Clark, 4 November, Alanya Tersane, 1221 is the Mediterranean's oldest dockyard, but other archetypal dockyard structures, as in Venice, missing. Byzantines \& Ottomans learnt much from the Arsenale, Private Communication, 2014.

[5] Lane, F., Venetian Ships\& Shipbuilders of the Renaissance, John Hopkins, 1934.

[6] Rossi, F., Un 'rasonato' alia fine del '500: Bartolomeo Tadini', in Zambon S., a cura di, Alle origini della revisione cantabile, il Mulino: Bologna, 1997.

[7] Zan, L., Accounting and management discourse in proto-industrial settings: The Venice Arsenal in the turn of the 16th century Accounting and Business Research 32(2), pp. 145-175, 2004, Oxford, 1994.

[8] Clark, C., Vintage Ports or Deserted Dockyards: Differing Futures for Naval Heritage across Europe. Working Paper No. 57. Research Consultancy for University of the West of England, Bristol, ISBN I 86043281, 6116 pages, 2000.

[9] Gordon, C., Email to Celia Clark. 7 December 2015.

[10] Menichelli, C. (ed.), On site interpretation, 2014.

[11] Clarke, Lady F., The project to preserve the Armstrong Mitchell hydraulic crane in the Venice Arsenale. Dockyards Newsletter of the Naval Dockyards Society, 12(1), pp. 5-6, Portsmouth, 2007.

[12] Clark, C., The future of Dockyard heritage conservation, community and economic aspects of the transition of naval and military sites to civilian use in four former Dockyard Towns: Chatham, Portsmouth, Plymouth and Venezia, MSc. Dissertation, Oxford Brookes University, School of Planning and University of Oxford, Department of Continuing Education, 1994.

[13] Brusatin, M., The Tana reopened: Machines and workshops of the Arsenal of Venice. The Presence of the Past. First International Exhibition of Architecture - Venice 
Biennale 80, eds. P. Portoghesi, V. Scully, C. Jencks \& C. Norberg-Schulz, Academy Editions: London, 1980.

[14] Prosdocimi, F., Naval Library, Venice Arsenale, 6 May, Email to C. Clark, 2014.

[15] Owen, R., Nicolas Sarkozy urged to pay for Napoleon's 'vandalism' of golden barge' The Times, London, 23 February 2008.

[16] Haslam, R., The Arsenale: The Future. The Venice in Peril Fund Newsletter, 2014.

[17] Charlton, C., Available at www.dailymail.co.uk/news/article-2853457/Venice-sline-defence-New-anti-flood-aims-protect-historic-Italian-city-rising-waters.html 2014; www.mosevenezia.eu 2015; www.magisacque.it 2015.

[18] www.wessex.ac.uk/14-conferences/defence-heritage-2014.html

[19] Clark, C. \& Brebbia, C. (eds.), Defence Sites Heritage and Future, First International Conference Wessex Institute of Technology, WIT Press, Vol. 123 of WIT Transactions on the Built Environment, ISSN 1743-3509 2012.

[20] Clark, C. \& Brebbia, C. (eds.), Defence Sites Heritage and Future II, Wessex Institute of Technology, WIT Press, Vol. 143 of WIT Transactions on the Built Environment, 2014.

[21] Hewison, R., 'A singular figure' Sunday Times Culture, pp. 12-13, 5 October 2014.

[22] Dartington Amenity Research Trust, Defence of the Realm an interpretive strategy for Portsmouth and the surrounding region, City of Portsmouth Southern Tourist Board, DART publication, No. 59, 1979.

[23] National Trust for Historic Preservation. 'What We Do.' Available at PreservationNation.org (accessed 15 January 2014).

[24] Timothy, D. \& Boyd, S., Heritage Tourism, Harlow: Prentice Hall, 2003.

[25] Ashworth, G., War and The City, Routledge: London \& New York, 1991.

[26] Tunbridge, J. \& Ashworth, G. Dissonant Heritage: The Management of the Past as a Resource in Conflict, J. Wiley Chichester: New York, 1996.

[27] Mack, B., Tourism overwhelms vanishing Venice 9 November, available at http://www. dw.de/tourism-overwhelms-vanishing-venice/a-16364608, 2012.

[28] http://www.comune.venezia.it/flex/cm/pages/ServeBLOB.php/L/FR/IDPagina/53175 (accessed 16 October 2015).

[29] Italy Magazine, available at www.italymagazine.com/italy/venice/venice-discussestourist-entry-toll (accessed 29 February 2008).

[30] Clark, C., Dockyards in Visual Art; Art in Dockyards: Celebrated as sites of national pride expressing the 'beauty of utility', pride in craft skills and foci of new artistic activity', in Treason's Harbours: Dockyards in Art, Literature and Film. Transactions Naval Dockyards Society 14th Annual Conference, National Maritime Museum, Greenwich, UK, pp. 43-64, 2014.

[31] Clark, C., Make art not war: Defence sites find new life as centres of creativity, Defence Sites II Heritage and Future, 2nd International Conference on Defence Sites Heritage and Future Venice, eds. C.A. Brebbia \& C. Clark, WIT Press: pp. 113-123, 2014.

[32] http://www.veniceinperil.org/projects/armstrong-mitchell-crane (accessed 16 January 2016)

[33] labiennale.org/en/biennale/venues/arsenale.html?back=true, 2015 (accessed 16 January 2016).

[34] La Biennale Di Venezia Press release, Great Success of the Biennale Architettura, 23 November 2014, 14. Mostra Internazionale di Architettura, 2014.

[35] Deutscher Welle, 9 August 2014, available at http://www.dw.de/big-ships-to-bebarred-from-central-venice-lagoon/a-17842721, msh/jr (AFP, dpa, Reuters) (accessed 6 October 2014). 